Short Paper

\title{
Effect of Sarcoplasmic Proteins on the Setting of Transglutaminase-free Paste
}

\author{
Alam AKM Nowsad, Emi Katoh, Satoshi Kanoh, \\ and Eiji Niwa \\ Faculty of Bioresources, Mie University, Tsu, Mie 514, Japan \\ (Received December 12, 1994)
}

Key words: setting, Spanish mackerel, sarcoplasmic proteins, transglutaminase

It has long been believed that sarcoplasmic proteins (SP) in fish flesh reduced the elasticity of resultant kamaboko. It was observed, however, that the suwari gel from Alaska pollack surimi was weakened by washing it repeatedly but was strengthened again by returning wash water to it.* This dichotomy was resolved by finding the existence of transglutaminase (TGase) in SP. In this paper, we describe the effect of SP from various fish fleshes on the suwari gel formability of TGase-free paste.

TGase-free Spanish mackerel Scomberomorus niphonius paste was prepared by washing its mince 6 times, and SP were extracted from Alaska pollack Theragra chalcogramma frozen surimi and the muscles of other fish." TGase activity of the mince was measured as previously. "The TGase-free mince was ground together with $3 \% \mathrm{NaCl}$ (in the weight of the mince) with or without SP in a mortar for $8 \mathrm{~min}$ at $4^{\circ} \mathrm{C}$. The amount of SP added to the mince was $4.0,3.0,3.3,4.2,3.0$, and 3.6\% for Alaska pollack, sardine Sardinops melanosticta, horse mackerel Trachurus japonicus, Pacific mackerel Pneumatophorus japonicus, carp Cyprinus carpio, and Spanish mackerel, respectively, and the final water content of resulting paste was adjusted to $87 \%$. The paste was stuffed into glass tubes (10 $\mathrm{mm}$ inner diameter, $45 \mathrm{~mm}$ length), and set in a water bath at $40^{\circ} \mathrm{C}$ after wrapping both ends of the tubes and cooled in ice-water. Puncture tests and SDS-polyacrylamide gel electrophoresis were done on the resulting suwari gel as previously.

The TGase activity of the mince was reduced by the washings to $0.00 \mathrm{nmol}$ monodansylcadaverine (MDC) $/ \mathrm{mg}$ protein $/ \mathrm{h}$ and remained intact after setting for $5 \mathrm{~h}$ (Table 1). For the minces with the above amount of SP added, the activity was increased during incubation up to nearly the same as the extent shown in Spanish mackerel mince washed once, suggesting that the level of TGase activity was nearly the same for all the minces.

Figure 1 shows the effect of various SP on the breaking force of the suwari gel. The force was increased at the initial stage of setting, and somewhat decreased thereafter. This increment was enlarged by the addition of SP in the order of Alaska pollack, Pacific mackerel, sardine, horse mackerel, carp, and Spanish mackerel, nearly in the same order as that of suwari gel formability of fish paste depending on species. ${ }^{2)}$

Figure 2 shows the effect of SP on the amount of myosin heavy chain (MHC) and cross-linked $\mathrm{MHC}(\mathrm{CMHC})$ in the suwari gels. The cross-linking of MHC was scarce in the suwari gels formed without SP, but accelerated by the addition of SP. This acceleration was greater in the order of Alaska pollack, sardine, horse mackerel, Pacific mackerel, carp, and Spanish mackerel, and was nearly the same as the order of gel formability.

The extent of enzymic action of TGase was found to be influenced also by the conformational factor of substrate proteins, depending on fish species. ${ }^{3)}$ In this study, the effect of various SP on the setting of TGase-free Spanish mackerel paste was examined, from which TGase could be easily removed. It was observed that the increment of breaking force and the acceleration of the cross-linking of MHC was more intense in the gel added with SP from the

Table 1. Changes in the TGase activity of Spanish mackerel mince during incubation at $40^{\circ} \mathrm{C}$

(nmol/mg protein)

\begin{tabular}{|c|c|c|c|c|c|c|c|c|}
\hline \multirow{3}{*}{$\begin{array}{c}\text { Incubation } \\
\text { time } \\
\text { (h) }\end{array}$} & \multicolumn{8}{|c|}{ Incorporated $\mathrm{MDC}$} \\
\hline & \multirow{2}{*}{$\begin{array}{l}\text { TGase-free } \\
\text { mince }\end{array}$} & \multirow{2}{*}{$\begin{array}{c}\text { Mince } \\
\text { washed } \\
\text { once }\end{array}$} & \multicolumn{6}{|c|}{ SP added mince } \\
\hline & & & $\begin{array}{l}\text { Alaska } \\
\text { pollack }\end{array}$ & Sardine & $\begin{array}{c}\text { Horse } \\
\text { mackerel }\end{array}$ & $\begin{array}{l}\text { Pacific } \\
\text { mackerel }\end{array}$ & Carp & $\begin{array}{l}\text { Spanish } \\
\text { mackerel }\end{array}$ \\
\hline 1 & 0.00 & 0.33 & 0.34 & 0.33 & 0.34 & 0.33 & 0.35 & 0.34 \\
\hline 3 & 0.00 & 0.43 & 0.46 & 0.42 & 0.39 & 0.38 & 0.39 & 0.41 \\
\hline 5 & 0.00 & 0.71 & 0.63 & 0.67 & 0.66 & 0.70 & 0.59 & 0.73 \\
\hline
\end{tabular}

* K. Arai and N. Seki: in "The Year Showa 63, Technology for the Utilization of Effective Nutrient Components in Fish and Shellfish", Research Div., Fisheries Agency, Japan, 1989, pp. 463-471. 


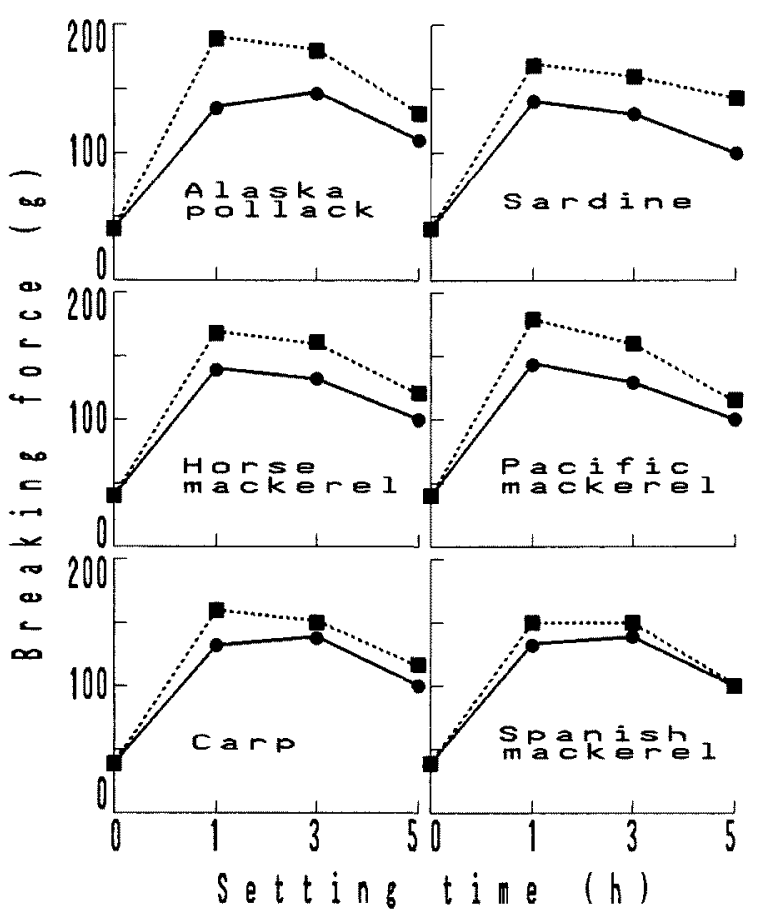

Fig. 1. Effect of various SP on the breaking force of the suwari gels prepared from TGase-free Spanish mackerel mince at $40^{\circ} \mathrm{C}$.

Source of SP is written in each graph. --, gel formed without SP; - --, one formed with SP.

fish showing high suwari gel formability, although the TGase activity of all the minces was adjusted to nearly the same level. Is the action of TGase to MHC different from that action to $\mathrm{MDC}$, or is there any substance which inhibits the cross-linking of MHC contained in the fish showing low suwari gel formability?

\section{References}

1) A. AKM. Nowsad, S. Kanoh, and E. Niwa: Fisheries Sci., 61, 79-81 (1995)

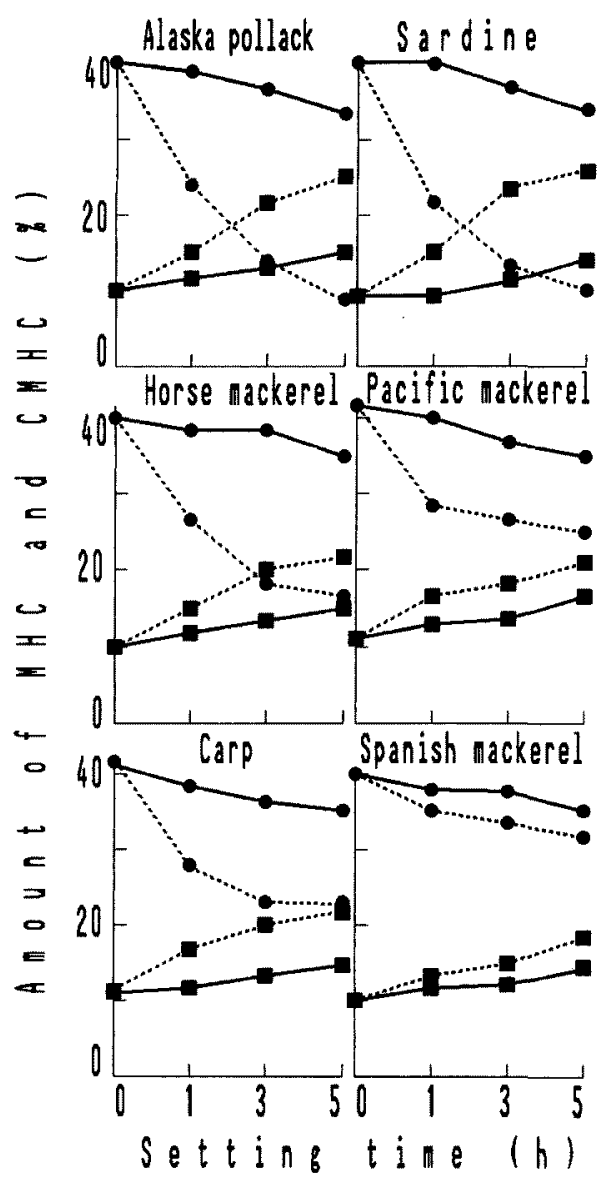

Fig. 2. Effect of various $\mathrm{SP}$ on the amount of $\mathrm{MHC}$ and $\mathrm{CMHC}$ in the suwari gels prepared from TGase-free Spanish mackerel mince at $40^{\circ} \mathrm{C}$.

Source of SP is written in each graph. Solid line, gel formed without SP; dotted line, one formed with SP;,$-- \mathrm{MHC}_{--1}^{-}$ CMHC.

2) Y. Shimizu, R. Machida, and S. Takenami: Nippon Suisan Gakkaishi, 47, 95-104 (1981).

3) H. Araki and N. Seki: Nippon Suisan Gakkaishi, 59, 711-716 (1993). 